\title{
ASSESSMENT THE UNIFORMITY OF LOW HEAD BUBBLER IRRIGATION SYSTEMS
}

\author{
Mohamed A. Rashad*
}

\section{ABSTRACT}

This study aims to evaluate the effect of low pressure and bubbler tube diameter on discharge uniformity $(\boldsymbol{C u})$ when using a simple and complex design of low head bubbler irrigation. Three available tube diameters $\phi$ 3.8, 5.2 and $13.6 \mathrm{~mm}$ in the local market at three initial pressure of 15, 30 and $45 \mathrm{kPa}$ were considered. In the simple design, the bubbler tube height levels were 0.0, 0.2, 0.4, 0.6, 0.8 and $1.0 \mathrm{~m}$. Excellent $\boldsymbol{C u}$ values were recorded with small tubes $\phi 3.8$ and $5.2 \mathrm{~mm}$ with all heights at all initial pressure $\left(\boldsymbol{P}_{i}\right)$. While $\boldsymbol{C u}$ values were not reaching a good classification with $\phi 13.6 \mathrm{~mm}$ in all treatments.

In the complex design, it was considered a full uniformity with $\phi 3.8$ and $5.2 \mathrm{~mm}$ with all operating pressures $P_{o}$ at all initial pressures. While, the $\phi 13.6 \mathrm{~mm}$ diameter discharge uniformity was achieved excellent and good classification with all operating pressures at initial pressures 15 and $30 \mathrm{kPa}$, respectively.

Key words: bubbler tube, Pressure, design, Uniformity.

\section{INTRODUCTION}

7 me main goal of irrigation is to achieve optimal agricultural production and maximum economic return. A well-designed 1 microirrigation system can help achieve this goal through its highly uniform water application. A microirrigation system is defined as a localized irrigation system that can deliver water directly into the crop root zone. Water and energy saving are the most important advantage which is smaller than other irrigation systems. The high cost of installation, operation, and maintenance of microirrigation systems remains a major constraint to microirrigation expansion. The low pressure (about 10 to 50 $\mathrm{kPa}$ ) tube irrigation is one of the microirrigation systems. Water is applied to the soil surface as a little stream, typically from a small tube diameter ( 1 to $13 \mathrm{~mm}$ ).

" Lecturer, Agric. Eng. Dept., Fac. of Agric., Suez Canal University, 41522 Ismailia, Egypt. 
Water distributed to the tubes by adjusting the elevations of the tube outlets along the lateral so that water flows out from all hoses at approximately equal rates. This type are prefeared than other microirrigation systems by its low requirements of the installation, operation and maintenance (Hull,

\section{1; Lamm et al. 2007).}

The assessment of irrigation uniformity is the key to efficient irrigation. Nakayama and Bucks (1986) studied the relationship between emitter flow variation and uniformity coefficient and reported that a uniformity coefficient of about (98\%) equal an emitter flow variation of (10\%) and a uniformity coefficient of about (95\%) equals an emitter flow variation of (20\%). Habib and Awady (1992) stated that the discharge uniformity from tube irrigation system is controlled by varying the tube diameter and/or length and/or using valve for each tube along lateral line.

Rashad (2013) developed a model which optimize the design of low head bubbler irrigation by identifying tube height at each outlet point, maximum of outlet numbers, lateral length and flow. These results are identified using the data obtained from water temperatures, tubes and lateral diameters, allowable pressure and the soil slope. One of the main reasons for the lack of the current designs dissemination is the complex criteria of the models which need more simplification.

At the present, there is a few research associated with the difficulties of change of bubbler tube outlet heights along lateral lines from the practical point of view. So, the aim of this study was to evaluate the effect of different pressures and tube diameters on bubbler discharge uniformity when using a simple design (outlet heights at the same level) and complex design (outlet heights parallel to the hydraulic grade line).

\section{MATERIALS AND METHODS}

The experimental work for this study was conducted at the Farm of Agriculture Faculty, Suez Canal University. Figure (1) shows the experimental low head bubbler irrigation system which can be described in the following steps: By using centrifugal pump powered using electric motor 3 horse power, 220 volts, the water is pumped from the water source to a cylindrical plastic tank with dimensions; height $0.9 \mathrm{~m}$, diameter $0.49 \mathrm{~m}$ with $0.17 \mathrm{~m}^{3}$ capacity. Using an over flow pipe with diameter $50 \mathrm{~mm}$, the 
water level in the tank was kept constant. The tank was located on adjustable base to three initial pressure head levels at $1.5,3.0$ and $4.5 \mathrm{~m}$ $(15,30$ and $45 \mathrm{kPa})$. The main pipe branched to two submain pipes with one lateral mounted in each one. To control and flushing the air from the irrigation system, two relief valves were mounted on entrance and end of each lateral. The lateral pipe was a smooth polyethylene with $30 \mathrm{~m}$ length and diameter $32 \mathrm{~mm}(\phi, 28 \mathrm{~mm}$ internal diameter). The lateral pipe was in the same level. Five tubes with length $5 \mathrm{~m}$ were mounted on each lateral pipe with $6 \mathrm{~m}$ space between them. The smooth polyethylene bubbler Tubes were available in the local irrigation kits market with internal diameter $\phi$ 3.8, 5.2 and $13.6 \mathrm{~mm}$.

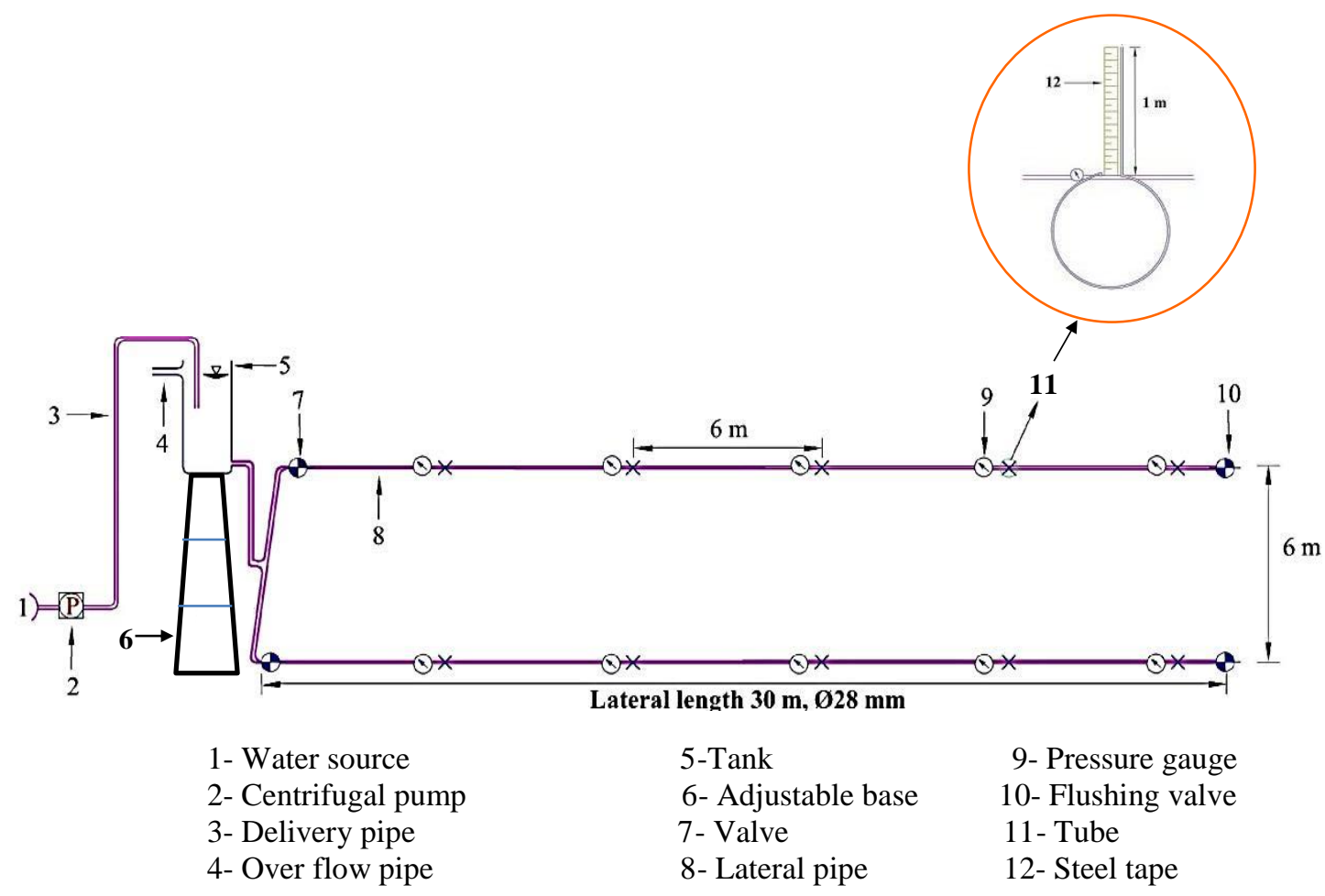

Figure (1). The experimental setup diagram.

\section{Uniformity coefficient}

The effect of bubbler hight on Uniformity coefficients was studied at six levels from zero to one meter. The Christiansen's formula (1942) was 
used to give the information about how efficiently water is distributed in the field.

$$
C u=100\left(1-\frac{\sum_{i=1}^{i=n}\left|q_{i}-\bar{q}\right|}{\bar{q} n}\right)
$$

Where

$\boldsymbol{C u}=$ Coefficient of uniformity.

$\boldsymbol{q}_{i}=$ Tube flow rate.

$\overline{\boldsymbol{q}}=$ Average of tube flow rate values.

$\boldsymbol{n}=$ Total number of observation points.

$\sum_{i=1}^{i=n}\left|\boldsymbol{q}_{\boldsymbol{i}}-\overline{\boldsymbol{q}}\right|=$ Summation of absolute values deviation from the mean tube flow rate.

The coefficient of uniformities, standards/ classifications is presented by ASAE standards EP458 (1999). Micro-irrigation system uniformity classifications based on uniformity coefficient are presented in Table (1).

Table (1). Classification/standards of uniformity coefficient

\begin{tabular}{|l|l|}
\hline Uniformity coefficient, $\boldsymbol{C U}(\boldsymbol{\%})$ & classification \\
\hline Above $90 \%$ & Excellent \\
\hline $90-80 \%$ & Good \\
\hline $80-70 \%$ & Fair \\
\hline $70-60 \%$ & Poor \\
\hline Below $60 \%$ & Unacceptable \\
\hline
\end{tabular}

\section{RESULTS AND DISCUSSION}

The results of the study can be presented by simple and complex designs.

\section{a. Bubbler Outlets at the Same Elevation}

Table 2 presents the influnced of operating pressures $\left(\boldsymbol{P}_{\boldsymbol{o}}\right)$ by the bubbler tube diameter and the variation in outlet elevation at the same initial pressure. In all tube diameters, the operating pressure had inverse relationship with bubbler heights at the same initial pressure. The Bubbler discharge was increased proportionally with increasing the operating pressure for all tube diameters. Generally, the mean bubbler discharge $(\overrightarrow{\boldsymbol{q}})$ was decreased and the discharge uniformity coefficients $(\boldsymbol{C u})$ increased by increasing the heights $\left(\boldsymbol{h}_{\boldsymbol{b}}\right)$ from 0.0 to $1.0 \mathrm{~m}$ at the all initial pressures for all tube diameters. 
The uniformity coefficients $(\boldsymbol{C} \boldsymbol{u})$ were excellent values and more than $98.0 \%$ at all bubbler heights $\left(\boldsymbol{h}_{\boldsymbol{b}}\right)$ from 0.0 to $1.0 \mathrm{~m}$ with all initial pressure $\left(\boldsymbol{P}_{i}\right)$ for $\boldsymbol{\phi} 3.8 \mathrm{~mm}$. Also for $\boldsymbol{\phi} 5.2 \mathrm{~mm}, \boldsymbol{C u}$ were excellent and tended to increase from (94.4 to $95.6 \%$ ) to (99.2 to $99.4 \%$ ) by increasing $\boldsymbol{P}_{\boldsymbol{i}}$ from 15 to $30 \mathrm{kPa}$ and decreased to $96.8 \%$ by increasing $\boldsymbol{P}_{\boldsymbol{i}}$ from 30 to $45 \mathrm{kPa}$. While $\boldsymbol{C} \boldsymbol{u}$ for $13.6 \mathrm{~mm}$ were decreased at all heights $\left(\boldsymbol{h}_{\boldsymbol{b}}\right)$ from (65.8 to $72.8 \%)$, (56.0 to $62.2 \%$ ) and (61.8 to $54.2 \%)$ with initial pressure 15,30 and $45 \mathrm{kPa}$ at all heights $\left(\boldsymbol{h}_{\boldsymbol{b}}\right)$, respectively.

The excellent discharge uniformity values were recorded with $\phi 3.8$ and 5.2 $\mathrm{mm}$. While $\boldsymbol{C} \boldsymbol{u}$ values for $13.6 \mathrm{~mm}$ were just fair at initial pressure of 15 $\mathrm{kPa}$ with one meter height and poor with other heights from 0.0 to $0.9 \mathrm{~m}$ nothing else and considered unacceptable with almost heights at $\boldsymbol{P}_{\boldsymbol{i}}$ of 30 and $45 \mathrm{kPa}$. Based on the previous results, it is not recommended to use relatively large tube diameter as $\phi 13.6 \mathrm{~mm}$ in case of tube outlets elevation at the same level. These results agree with Reynolds et al., (1995) which indicated that hose diameters greater than $10 \mathrm{~mm}$ are not recommended for low-head bubblersystems due to poor water distribution uniformity.

Table (2). Tube discharge and uniformity of different diameters at different initial pressure with same height levels.

\begin{tabular}{|c|c|c|c|c|c|c|}
\hline$P_{i}(k P a)$ & $\phi(\mathrm{mm})$ & $h_{b}(m)$ & $P_{o}(k P a)$ & $\bar{q}(\mathrm{l} / \mathbf{m i n})$ & Cu $(\%)$ & Classification \\
\hline \multirow{18}{*}{15} & \multirow{6}{*}{3.8} & 0.0 & 7.0 & 0.51 & 98.8 & Excellent \\
\hline & & 0.2 & 6.5 & 0.50 & 98.8 & Excellent \\
\hline & & 0.4 & 6.2 & 0.49 & 98.8 & Excellent \\
\hline & & 0.6 & 5.8 & 0.49 & 98.8 & Excellent \\
\hline & & 0.8 & 5.5 & 0.48 & 98.8 & Excellent \\
\hline & & 1.0 & 5.2 & 0.47 & 98.8 & Excellent \\
\hline & \multirow{6}{*}{5.2} & 0.0 & 13.0 & 1.03 & 94.4 & Excellent \\
\hline & & 0.2 & 12.1 & 1.00 & 94.4 & Excellent \\
\hline & & 0.4 & 11.8 & 0.99 & 94.6 & Excellent \\
\hline & & 0.6 & 11.4 & 0.97 & 94.6 & Excellent \\
\hline & & 0.8 & 11.0 & 0.95 & 94.8 & Excellent \\
\hline & & 1.0 & 10.6 & 0.94 & 95.6 & Excellent \\
\hline & \multirow{6}{*}{13.6} & 0.0 & 9.1 & 6.83 & 65.8 & Poor \\
\hline & & 0.2 & 8.6 & 6.66 & 66.2 & Poor \\
\hline & & 0.4 & 8.1 & 6.48 & 66.8 & Poor \\
\hline & & 0.6 & 7.8 & 6.35 & 68.4 & Poor \\
\hline & & 0.8 & 7.2 & 6.16 & 69.6 & Poor \\
\hline & & 1.0 & 6.8 & 6.00 & 72.8 & Fair \\
\hline
\end{tabular}


Table 2 (Continued)

\begin{tabular}{|c|c|c|c|c|c|c|}
\hline$P_{i}(k P a)$ & $\phi(\mathrm{mm})$ & $h_{b}(m)$ & $P_{o}(k P a)$ & $\bar{q}(\ell / \min )$ & Cu (\%) & Classification \\
\hline \multirow{18}{*}{30} & \multirow{6}{*}{3.8} & 0.0 & 24.4 & 0.68 & 98.8 & Excellent \\
\hline & & 0.2 & 23.4 & 0.68 & 98.8 & Excellent \\
\hline & & 0.4 & 22.8 & 0.67 & 98.8 & Excellent \\
\hline & & 0.6 & 22.1 & 0.67 & 98.8 & Excellent \\
\hline & & 0.8 & 21.3 & 0.66 & 98.8 & Excellent \\
\hline & & 1.0 & 20.7 & 0.66 & 98.8 & Excellent \\
\hline & \multirow{6}{*}{5.2} & 0.0 & 24.8 & 1.43 & 99.2 & Excellent \\
\hline & & 0.2 & 24.2 & 1.42 & 99.2 & Excellent \\
\hline & & 0.4 & 23.7 & 1.40 & 99.2 & Excellent \\
\hline & & 0.6 & 23.0 & 1.38 & 99.2 & Excellent \\
\hline & & 0.8 & 22.5 & 1.37 & 99.4 & Excellent \\
\hline & & 1.0 & 21.8 & 1.34 & 99.4 & Excellent \\
\hline & \multirow{6}{*}{13.6} & 0.0 & 15.7 & 8.70 & 56.0 & Unacceptable \\
\hline & & 0.2 & 15.0 & 8.53 & 56.8 & Unacceptable \\
\hline & & 0.4 & 14.4 & 8.39 & 57.6 & Unacceptable \\
\hline & & 0.6 & 14.1 & 8.30 & 58.0 & Unacceptable \\
\hline & & 0.8 & 13.7 & 8.17 & 58.6 & Unacceptable \\
\hline & & 1.0 & 13.1 & 8.02 & 62.2 & Poor \\
\hline \multirow{18}{*}{45} & \multirow{6}{*}{3.8} & 0.0 & 40.5 & 0.76 & 98.2 & Excellent \\
\hline & & 0.2 & 38.3 & 0.75 & 98.0 & Excellent \\
\hline & & 0.4 & 36.3 & 0.74 & 98.2 & Excellent \\
\hline & & 0.6 & 34.1 & 0.73 & 98.0 & Excellent \\
\hline & & 0.8 & 32.5 & 0.73 & 98.4 & Excellent \\
\hline & & 1.0 & 30.9 & 0.72 & 98.4 & Excellent \\
\hline & \multirow{6}{*}{5.2} & 0.0 & 35.6 & 1.72 & 96.8 & Excellent \\
\hline & & 0.2 & 34.7 & 1.70 & 96.8 & Excellent \\
\hline & & 0.4 & 33.9 & 1.68 & 96.8 & Excellent \\
\hline & & 0.6 & 33.1 & 1.66 & 96.8 & Excellent \\
\hline & & 0.8 & 32.2 & 1.64 & 96.8 & Excellent \\
\hline & & 1.0 & 31.2 & 1.61 & 97.0 & Excellent \\
\hline & \multirow{6}{*}{13.6} & 0.0 & 21.0 & 9.93 & 54.2 & Unacceptable \\
\hline & & 0.2 & 19.9 & 9.69 & 54.4 & Unacceptable \\
\hline & & 0.4 & 18.8 & 9.45 & 55.4 & Unacceptable \\
\hline & & 0.6 & 17.6 & 9.17 & 55.4 & Unacceptable \\
\hline & & 0.8 & 16.3 & 8.85 & 55.8 & Unacceptable \\
\hline & & 1.0 & 15.4 & 8.61 & 61.8 & Poor \\
\hline
\end{tabular}


Finally, the discharge uniformity was more sensitive to increase bubbler height with diameter $13.6 \mathrm{~mm}$ than small diameters. Also, there was inverse relationship between discharge and uniformity, as a result the discharge uniformity increased with heights increasing which agrees with EImeseery (1993). From a practical point of view, this study recommended to use diameter 5.2 compared to $3.8 \mathrm{~mm}$ with low pressure less than $30 \mathrm{kPa}$ due to airlock and clogging problems. However, it is possible to use 3.8 or 5.2 $\mathrm{mm}$ with pressures more than $30 \mathrm{kPa}$.

\section{b. Bubbler Outlets Parallel to the Hydraulic Gradient Line}

The bubblers discharge were measured when its outlets parallel to the hydraulic gradient line. The relationship between tube diameters $\phi$, initial pressure $\boldsymbol{P}_{\boldsymbol{i}}$, operating pressure $\boldsymbol{P}_{\boldsymbol{o}}$, mean tube discharge $\overline{\boldsymbol{q}}$ and The uniformity coefficients $(\boldsymbol{C u})$; were displayed in Table (3). The discharge uniformities were higher in the complex design than the simple one in all diameters. The discharge uniformities were insignificant change in the two designs with small diameters $\phi(3.8$ and $5.2 \mathrm{~mm})$, but the two cases still have higher classification. However there is a high change with relatively large diameters $\phi 13.6 \mathrm{~mm}$.

Table (3). Tube hydraulic properties of different diameters and locations at same pressure.

\begin{tabular}{|c|c|c|c|c|l|}
\hline $\boldsymbol{\phi}(\boldsymbol{m m})$ & $\boldsymbol{P}_{\boldsymbol{i}}(\boldsymbol{k P a})$ & $\boldsymbol{P}_{\boldsymbol{o}}(\boldsymbol{k P a})$ & $\overline{\boldsymbol{q}}(\boldsymbol{\ell} / \mathbf{m i n})$ & $\boldsymbol{C u}(\boldsymbol{\%})$ & \multicolumn{1}{|c|}{ Classif. } \\
\hline \multirow{3}{*}{3.8} & 15 & 7 & 0.51 & 99.2 & Excellent \\
\cline { 2 - 6 } & 30 & 27 & 0.7 & 99.2 & Excellent \\
\cline { 2 - 6 } & 45 & 39 & 0.75 & 99 & Excellent \\
\hline \multirow{3}{*}{5.2} & 15 & 11 & 0.95 & 98.8 & Excellent \\
\cline { 2 - 6 } & 30 & 28 & 1.52 & 99.3 & Excellent \\
\cline { 2 - 6 } & 45 & 31 & 1.6 & 98.9 & Excellent \\
\hline \multirow{3}{*}{13.6} & 15 & 8 & 6.44 & 94.6 & Excellent \\
\cline { 2 - 6 } & 30 & 13 & 8 & 82.8 & Good \\
\cline { 2 - 6 } & 45 & 23 & 10.35 & 59.6 & Unacceptable \\
\hline
\end{tabular}

On the other hand, with all operating pressures $\boldsymbol{P}_{\boldsymbol{o}}$ at all initial pressures $(15,30$ and $45 \mathrm{kPa})$, there is almost full discharge uniformity for small diameters 3.8 and $5.2 \mathrm{~mm}$. The discharge uniformity was more sensitive to increasing the tube height with diameter $\phi 13.6 \mathrm{~mm}$ than the small 
diameters. $\boldsymbol{C u}$ classification for $\boldsymbol{\phi} 13.6 \mathrm{~mm}$ at initial pressure of 15,30 and $45 \mathrm{kPa}$, was decreased from excellent to good and unacceptable respectively, which agrees with the results of Ngigi (2008).

From a practical point of view, based on the results of the complex design, it is not recommended to use diameter $\phi 13.6 \mathrm{~mm}$ with initial pressures more than $30 \mathrm{kPa}$. However, it is possible to use 3.8 or $5.2 \mathrm{~mm}$ with pressures more than $30 \mathrm{kPa}$. For the diameter $3.8 \mathrm{~mm}$, it is not recommended to use the initial pressures less than $30 \mathrm{kPa}$ due to the reasons which mentioned in the simple design.

\section{CONCLUSION}

The discharge uniformity was studied in two designs: simple design (tube outlets at the same level) and complex design (tube outlets parallel to the hydraulic grade line). In the simple design, there was inverse relationship between discharge and uniformity. The excellent values of discharge uniformity $(\boldsymbol{C u})$ were recorded with $\boldsymbol{\phi} 5.2$ and $3.8 \mathrm{~mm}$ at all initial pressures with all outlet heights for all diameters, while $(\boldsymbol{C u})$ values was considered a unacceptable for $\phi 13.6 \mathrm{~mm}$. So this study do not recommended the using of relatively large tube diameters as $\phi$ 13.6.

On the other hand, in the complex design, the discharge uniformities were higher than the simple one in all diameters. With all operating pressures $\boldsymbol{P}_{\boldsymbol{o}}$ at all initial pressures $(15,30$ and $45 \mathrm{kPa})$, there is almost full discharge uniformity for small diameters 3.8 and $5.2 \mathrm{~mm}$. From a practical point of view, it is not recommended to use diameter $\phi 13.6 \mathrm{~mm}$ with initial pressures more than $30 \mathrm{kPa}$.

However in the two desgins, it is possible to use 3.8 or $5.2 \mathrm{~mm}$ with pressures more than $30 \mathrm{kPa}$. For the diameter $3.8 \mathrm{~mm}$, it is not recommended to use the initial pressures less than $30 \mathrm{kPa}$ due to airlock and clogging problems.

\section{REFERENCES}

ASAE Standards. EP 458 (1999): Field evaluation of micro irrigation systems. St. Joseph, Michigan, ASAE.918- 924.

El-Meseery A. A. (1993). A study on some factor affecting on bubbler irrigation, Unpublished M.SC. Thesis, Department of Agricultural 
Engineering, Faculty of Agriculture, Al-Azhar University, Egypt 16-18 and 39-40.

Habib, I. M. and Awady, M. N. (1992). Irrigation methods of desert land, Text book, Open Ed., Cairo University: 326-393. (In Arabic).

Hull, P.J. (1981): A low pressure irrigation system for orchard tree and plantation crops. The Agricultural Engineer. 55-58.

Lamm, F. R.; Ayars, J. E. and Nakayama, F. S. (2007). Micro-irrigation for crop production: design, operation, and management. 13th ed., Italy. Elsevier Co: 533-570.

Nakayama, F. S. and Bucks, D. A. (1986). Trickle irrigation for crop production, Elsevier Co: 11-17.

Ngigi. S. N. (2008). Technical evaluation and development of low-head drip irrigation systems in Kenya. Irrig. and Drain.Vol. 57: 450-462.

Rashad, M. A. (2013). Development a program to optimize design of low head bubbler irrigation. Misr J. Ag. Eng., Irrigation and Drainage, 30 (3): $765-784$.

Reynolds, C. A.; Yitayew, M. and Peterson, M. S. (1995). Low-head bubbler irrigation systems - Part I: Design. Agriculture and Water Management. Vol 29:1-24.

\section{الملخص العربي \\ تقييم انتظامية نظم ري فوار منخفضة الضاغط الضطي

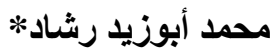

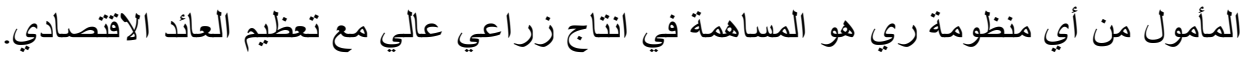

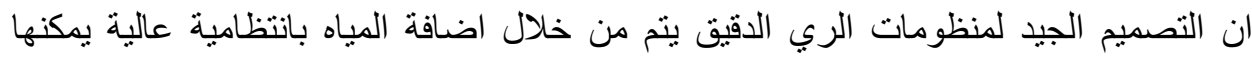

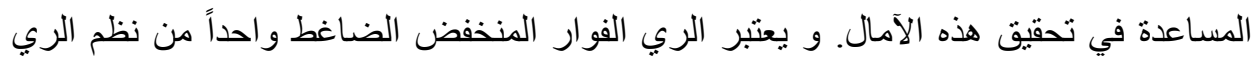

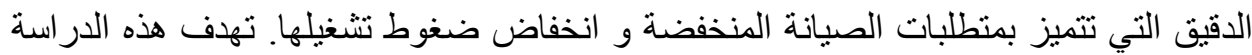

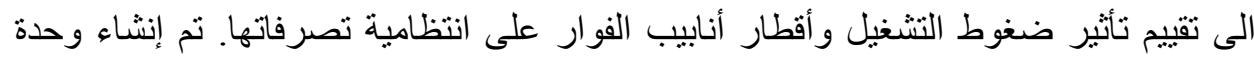

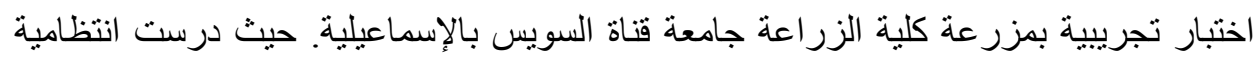

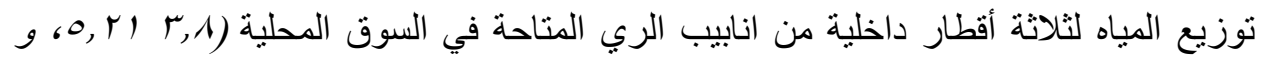

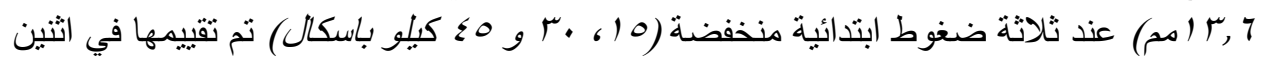

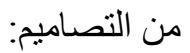

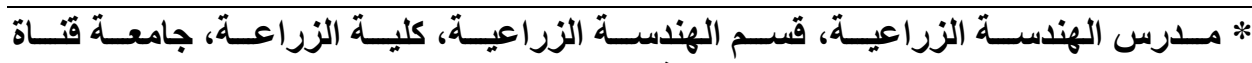

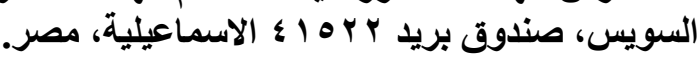




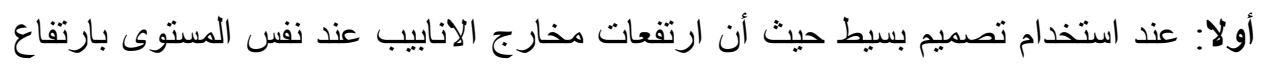

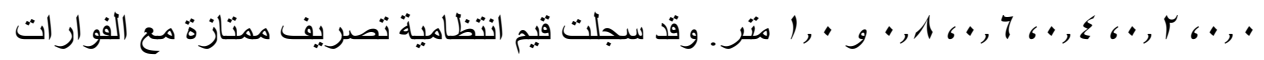

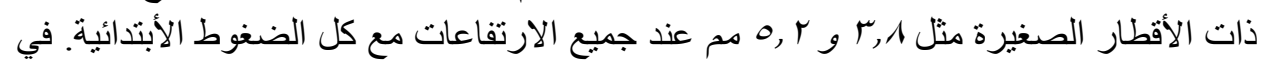
حين ان القطر 1\%, 7 مم لم يصل الى مستويات جيدة مع كل المعاملات. ثاتيا: التصميم المعقد عندما تكون ارتفعات مخارج الفوارات موازية لخط التدرج الهيدروليكي .

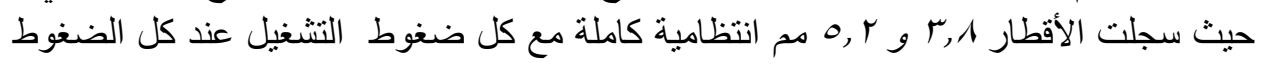

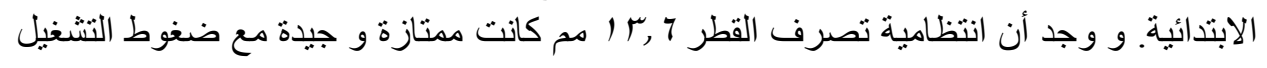

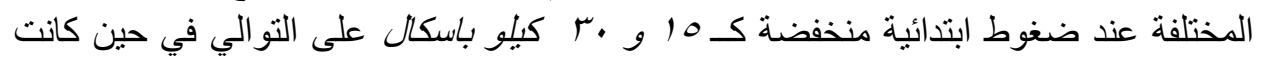
غير مقبولة مع 0 ء كيلو باسكال.

و يتضح من الدراسة أنه لا يوجد اختلافات معنوية في قيم انتظامية التصرف ما بين التصميم

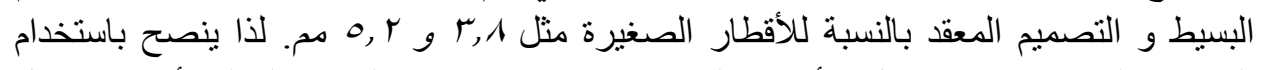

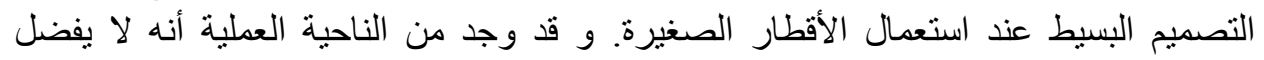

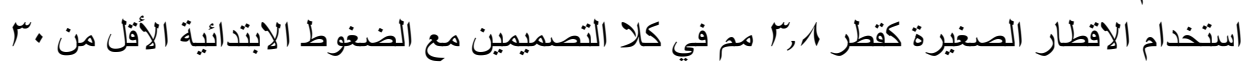

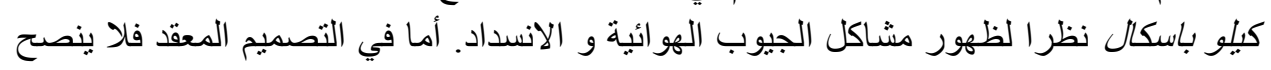
باستخدام الأقطار الكبيرة مع ضغوط ابتدائية أكبر من • مب كبلو باسكال. 